\title{
ANALISIS KETERAMPILAN PROSES SAINS PESERTA DIDIK MELALUI BAHAN AJAR MULTIMEDIA INTERAKTIF ALAT UKUR DAN PENGUKURAN DENGAN PENDEKATAN BEHAVIORISTIK
}

\author{
Ino Angga Putra*), Eko Sujarwanto \\ Program Studi Pendidikan Fisika, Universitas KH. A. Wahab Hasbullah, Indonesia
}

\begin{abstract}
The development of science and technology today is spreading rapidly in the field of education, especially in the development of learning media. The application of learning media using behavioristic approach that tends to optimize the stimulus and learners' response in process (science process skill). The purpose of this research is a) to describe the application of interactive multimedia teaching materials to the students 'science process skills and b) to know the impact of interactive multimedia materials on the students' learning process skill. The type of this research is Pre-Experimental Research by using one-shot case study design. Implementation of research product in field can develop skill of science process learners based on result of $T$ test 2,229 significance of 0.056. It is expected that further research to determine the positive response of learners.
\end{abstract}

Keywords: interactive multimedia; measurement and measurement tools; behavioristic approach; science process skills

\begin{abstract}
Abstrak
Perkembangan IPTEKS dewasa ini menyebar secara cepat dibidang pendidikan khususnya dalam pengembangan media pembelajaran. Penerapan media pembelajaran tersebut menggunakan pendekatan behavioristik yang cenderung mengoptimalkan stimulus dan respon peserta didik dalam proses (keterampilan proses sains). Tujuan penelitian ini yaitu a) untuk mendeskripsikan penerapan bahan ajar multimedia interaktif terhadap keterampilan proses sains peserta didik dan b) untuk mengetahui dampak bahan ajar multimedia interaktif terhadap keterampilan proses sains peserta didik. Jenis penelitian ini adalah Penelitian Pre-Eksperimen dengan menggunakan desain one shot case study. Implementasi produk penelitian dilapangan dapat mengembangkan keterampilan proses sains peserta didik berdasarkan hasil Uji T sebesar 2.229 signifikansi 0.056 . Diharapkan adanya penelitian lanjutan untuk mengetahui respon positif peserta didik.
\end{abstract}

Kata Kunci: alat ukur dan pengukuran; keterampilan proses sains; multimedia interaktif; pendekatan behavioristik

DOI: http://dx.doi.org/10.21067/mpej.v1i2.2013

Diterima: Agustus 2017; Disetujui: September 2017

PENDAHULUAN

Perkembangan IPTEKS yang semakin cepat memaksa adanya perubahan

\footnotetext{
* Corresponding Author:

angga.putra2346@yahoo.co.id
}

disegala bidang. Salah satunya adalah dibidang pendidikan dimana pengembangan media di dunia pendidikan meningkat dan terus berkembang. Penggunaan dan pemanfaatan media 
(IPTEKS) didalam pembelajaran nantinya akan berdampak pada keterampilan peserta didik terkait proses pembelajaran. Hal ini terbukti oleh beberapa hasil pen penelitian para peneliti. Resta \& Laferriere (2007) pembelajaran dengan komputer dapat merubah suasana kelas menjadi interaktif dan komunikatif. Hal tersebut juga ditekankan oleh Husni, dkk. (2010) dan Demirci (2007) bahwa penggunaan komputer dan internet di dalam pembelajaran dapat meningkatkan pemahaman konsep peserta didik dan hasil belajar mereka.

Berdasarkan kenyataan di lapangan diketahui bahwa keterampilan proses sains peserta didik masih belum berkembang secara optimal dan maksimal. Kenyataannya materi Fisika menuntut peserta didik untuk aktif dalam belajar atau lebih ditunjukkan melalui keterampilan proses sainnya. Hal ini juga berkaitan dengan materi Alat Ukur dan Pengukuran yang cenderung pada kegiatan praktikum atau lebih ke arah aktivitas peserta didik. Selain itu, juga diperlukan adanya media pembelajaran yang dapat menunjang proses pembelajaran berlangsung serta meningkatkan keterampilan proses sains peserta didik. Upaya untuk mengatasi permasalahan yang muncul maka digunakan suatu pendekatan yang sesuai dengan kemampuan mendasar yang dengan penggunaan media pembelajaran lebih mengarah ke dalam proses belajar (keterampilan proses sains) yaitu melalui pendekatan behavioristik. Pendekatan behavioristik memandang bahwa perubahan tingkah laku sebagai akibat respon (Budiningsih; 2005 \& Wahyuni; 2010). Hal ini dipertegas oleh Sanyata (2012) bahwa behavioristik memandang perilaku individu sebagai hasil belajar yang dapat diubah dengan memanipulasi dan mengkreasikan kondisi-kondisi belajar dan didukung dengan berbagai penguatan dalam memepertahankan hasil belajar tersebut. Oleh karena itu, pendekatan behavioristik adalah suatu cara/langkah untuk mengembangkan dan melatih perilaku peserta didik di dalam kegiatan pembelajaran melalui pemberian stimulus pada peserta didik, pemerolehan respon dari peserta didik, dan pengkondisian baik pada proses belajar maupun hasil belajar.

Berkaitan dengan hal diatas maka perlu ditingkatkan keterampilan proses sains. Hal ini penting karena respon peserta didik terhadap pembelajaran didasarkan pada aktivitasnya berupa keterampilan proses sains. Semiawan, dkk. (1992) menyatakan bahwa keterampilan proses merupakan keterampilan fisik dan mental terkait adanya interaksi antara stimulus dengan 
dimiliki, dikuasai, dan diaplikasikan dalam melakukan pengamatan (observasi), b) suatu kegiatan ilmiah sehingga para mengelompokan (klasifikasi), c) ilmuwan berhasil menemukan sesuatu meramalkan (interpretasi), d) meramalkan yang baru. Hal ini dipertegas oleh (prediksi), e) mengajukan pertanyaan, f) Depdikbud (dalam Dimyati \& Mujiono, berhipotesis, g) merencanakan percobaan, 2006) menyatakan bahwa pendekatan h) menggunakan alat/bahan, i) keterampilan proses sebagai wawasan atau menerapkan konsep, dan j) berkomunikasi. panutan pengembangan keterampilan- Upaya dalam mendukung keterampilan intelektual, sosial, dan fisik pembelajaran dengan pendekatan yang bersumber dari kemampuan- behavioristik maka digunakan media kemampuan mendasar yang pada pembelajaran berupa media flipbook. prinsipnya sudah ada di dalam diri siswa. Menurut website animasi Teknokids Selain itu, keterampilan proses sains (2010), Flipbook adalah salah satu jenis merupakan betuk keterampilan dasar animasi klasik yang dibuat dari setumpuk dalam kajian Ilmu Pengetahuan Alam kertas menyerupai buku tebal dimana (IPA) (Sulastiani, dkk. 2012). setiap halaman digambarkan suatu hal Ditambahkan oleh Devi (2010) bahwa yang terlihat bergerak atau terdapat keterampilan proses sains merupakan animasi. Hal ini dapat ditunjukkan seperti bentuk perlakukan yang diterapkan dalam majalah, buku, komik, dan sebagainya. pembelajaran yang menekankan pada Media flipbook berisi informasi digital pembentukan keterampilan untuk yang dapat berbentuk teks atau gambar. memperoleh pengetahuan dan Selain itu, media ini juga dapat disisipi dikomunikasikan kembali. Berdasarkan dengan komponen audio, video, animasi, hal tersebut, keterampilan proses foto, dan sebagainya.

merupakan bentuk keterampilan yang Berdasarkan hal tersebut, maka mendasar baik secara fisik, intelektual, yang dikaji dalam penelitian ini meliputi: sosial, maupun mental yang berhubungan (1) bagaimana deskripsi keterampilan dengan kemampuan-kemampuan dasar proses sains melalui penerapan bahan ajar atau ilmiah yang sudah ada di dalam diri multimedia interaktif alat ukur dan tiap siswa/peserta didik. pengukuran dengan pendekatan

Ada beberapa jenis keterampilan behavioristik, dan (2) bagaimana pengaruh proses sains, salah satunya berdasarkan bahan ajar multimedia interaktif alat ukur Rustaman (2005) sebagai berikut a) dan pengukuran dengan pendekatan 
behavioristik terhadap keterampilan proses sains.

\section{METODE}

Jenis penelitian ini adalah penelitian Pre-Eksperimen. Desain penelitian yang digunakan adalah desain One-Shot Case Study. Populasi penelitian adalah peserta didik program studi pendidikan fisika yang sudah dan akan menempuh Mata Kuliah Alat Ukur dan Pengukuran. Instrumen penilaian dalam penelitian adalah (1) instrumen keterlaksanaan pembelajaran meliputi Silabus, dan SAP (Satuan Acara Pembelajaran), dan

Intrumen tes untuk keterampilan proses sains. Pengumpulan data penelitian dengan cara observasi instrumen perlakuan dan hasil keterampilan proses sains peserta didik. Analisa data deskripsi keterampilan proses sains diolah menggunakan teknik statistik deskriptif. Sedangkan, analisa data hasil keterampilan proses sains dengan bahan ajar multimedia interaktif berbasis pendekatan behavioristik dilakukan dengan menggunakan Uji Independent Sample $t$ dengan bantuan SPSS 20.0 for windows. Sebelumnya data diuji secara prasyarat analisis melalui uji normalitas sebaran data, uji homogenitas varians, dan uji korelasi antar variabel terikat.

\section{HASIL DAN PEMBAHASAN}

Hasil data penelitian analisis keterampilan proses sains melalui bahan ajar multimedia interaktif pada materi Alat Ukur dan Pengukuran menggambarkan secara umum pada Tabel 1, sebagai berikut:

Tabel 1. Skor Rata-Rata Secara Umum Keterampilan Proses Sains Peserta didik

\begin{tabular}{lllll}
\hline No & $\begin{array}{l}\text { Keterampilan } \\
\text { Proses Sains }\end{array}$ & $\begin{array}{r}\text { Rata } \\
\text { Rata }\end{array}$ & $\begin{array}{r}\text { Perce } \\
\text { ntase } \\
(\%)\end{array}$ & $\begin{array}{r}\text { Krite } \\
\text { ria }\end{array}$ \\
\hline 1 & $\begin{array}{l}\text { Melakukan } \\
\text { pengamatan } \\
\text { (observasi) }\end{array}$ & 3.11 & 78 & Baik \\
\hline 2 & $\begin{array}{l}\text { Mengelompokan } \\
\text { (klasifikasi) }\end{array}$ & 3.20 & 80 & Baik \\
\hline 3 & $\begin{array}{l}\text { Meramalkan } \\
\text { (interpretasi) }\end{array}$ & 2.70 & 68 & Baik \\
\hline 4 & $\begin{array}{l}\text { Meramalkan } \\
\text { (prediksi) }\end{array}$ & 2.69 & 67 & Baik \\
\hline 5 & $\begin{array}{l}\text { Mengajukan } \\
\text { pertanyaan }\end{array}$ & 2.89 & 72 & Baik \\
\hline 6 & berhipotesis & 2.81 & 70 & Baik \\
\hline 7 & $\begin{array}{l}\text { Merencanakan } \\
\text { percobaan }\end{array}$ & 3.11 & 78 & Baik \\
\hline 8 & $\begin{array}{l}\text { Menggunakan } \\
\text { alat/bahan }\end{array}$ & 3.02 & 75 & Baik \\
\hline 9 & $\begin{array}{l}\text { Menerapkan } \\
\text { konsep }\end{array}$ & 2.94 & 74 & Baik \\
\hline 10 & Berkomunikasi & 3.00 & 75 & Baik \\
\hline & Rata-Rata & $\mathbf{2 . 9 5}$ & $\mathbf{7 4}$ & Baik \\
\hline & & & \\
\hline
\end{tabular}

Berdasarkan Tabel 1 dapat dilihat bahwa keterampilan proses sains yang memiliki kriteria paling tinggi yaitu keterampilan melakukan pengamatan (observasi) dengan nilai rata-rata sebesar 3.11 (78\%) dan kriteria paling rendah yaitu keterampilan meramalkan dengan nilai rata-rata sebesar $2.69(67 \%)$.

Penilaian keterampilan proses sains dilakukan pada 2 bab yaitu Bab 2 Analisis 
Ketidakpastian di tahap 1 dan Bab 3 Alat

Ukur dan Pengukuran Panjang di tahap 2.

Hal ini dilakukan untuk mengetahui tingkat keterampilan proses sains peserta didik. Berikut hasil penilaian keterampilan proses sains peserta didik pada Tabel 2 .

Tabel 2 Hasil Nilai Keterampilan Proses Sains dan Penguasaan Konsep Peserta Didik

\begin{tabular}{cccc}
\hline No & Tahap & Aspek Penilaian & $\begin{array}{c}\text { Nilai Rata- } \\
\text { Rata }\end{array}$ \\
\hline 1 & 1 & KPS & 70.00 \\
\hline 2 & 2 & KPS & 77.87 \\
\hline $\mathrm{Nb} .:$ & KPS & : Keterampilan Proses Sains
\end{tabular}

Berdasarkan hasil penilaian keterampilan proses sains, tampak bahwa nilai rata-rata keterampilan proses sains peserta didik yang mengikuti pembelajaran dengan bahan ajar multimedia interaktif Alat Ukur dan Pengukuran yang dikembangkan secara lanjutan sebesar 77.87 lebih tinggi dibanding tahap pertama sebesar 70.00 dan nilai thitung 3.277 dengan taraf signifikansi 0.051 pada Tabel 3. Hal ini dapat dikatakan bahwa bahan ajar multimedia interaktif Alat Ukur dan Pengukuran dapat meningkatkan keterampilan proses sains.

Tabel 3 Hasil Uji-T pada Keterampilan Proses Sains Peserta Didik

\begin{tabular}{cccc}
\hline \multicolumn{3}{c}{ Paired Samples } & Test \\
\hline & $\mathrm{t}$ & $\mathrm{df}$ & $\begin{array}{c}\text { Sig. (2- } \\
\text { tailed) }\end{array}$ \\
\hline $\begin{array}{c}\text { Pair1 KPS11- } \\
\text { KPS22 }\end{array}$ & $-3,277$ & 8 & 0,051 \\
\hline
\end{tabular}

Bahan ajar yang dikembangkan dalam penelitian ini dapat digunakan sebagai sumber belajar dan melatih keterampilan proses sains peserta didik. Semua aspek keterampilan proses sains tersebut disesuaikan dengan kegiatan praktikum yang akan diberikan kepada peserta didik pada proses pembelajaran. Peserta didik diarahkan agar dapat mengembangkan keterampilan proses sains, memahami materi Alat Ukur dan Pengukuran Fisika, dan berlatih dalam menyelesaikan permasalahan (Putra, dkk. 2016). Hal ini sesuai dengan beberapa literatur yaitu hasil peneleitian Deta, dkk. (2013) dan Hayati, dkk. (2015) yang menyatakan bahwa bahan ajar multimedia interaktif (flip book) digunakan dalam proses pembelajaran untuk meningkatkan kegiatan kerja ilmiah peserta didik..

Tingkat keterampilan proses sains peserta didik dalam kategori baik. Dimana tingkat persentase keterampilan proses sains dengan bahan ajar multimedia interaktif Alat Ukur dan Pengukuran melalui pendekatan Behavioristik menunjukkan banyak perbedaan atau variasi yang ditunjukkan pada Gambar 1 . 


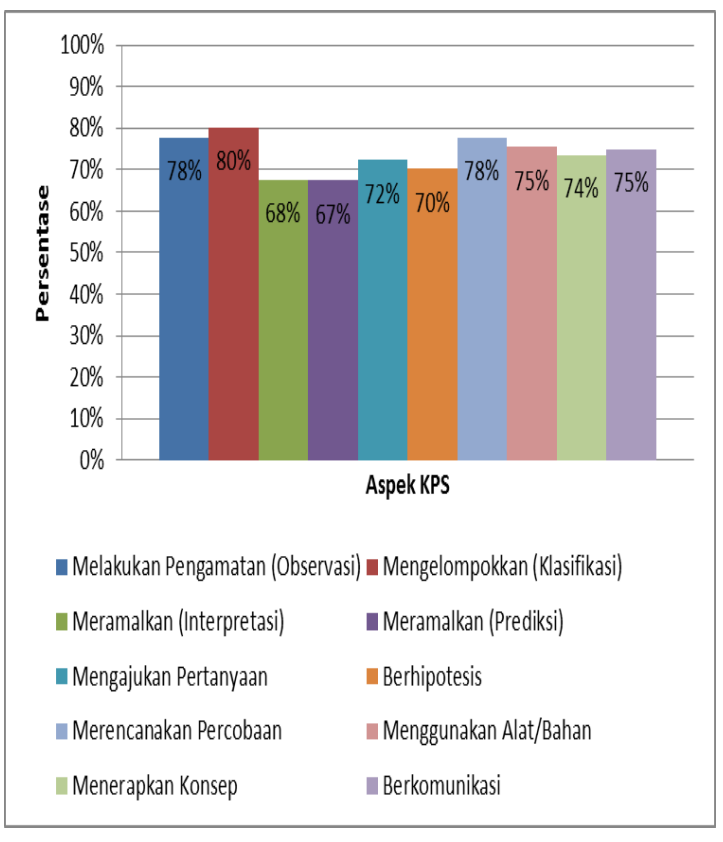

Gambar 1. Grafik Persentase Keterampilan Proses Sains

1. Aspek Melakukan Pengamatan (Observasi)

Pada aspek melakukan pengamatan (observasi) memiliki nilai persentase $78 \%$ dalam kategori baik. Aspek ini memiliki dua buah sub aspek yaitu sub aspek menggunakan semua indera dan sub aspek mengumpulkan fakta yang relevan. Sub aspek menggunakan indera dapat dilakukan dengan baik oleh peserta didik. Peserta didik mengamati pengukuran panjang untuk analisis ketidakpastiannya dan cara menggunakan alat ukur panjang. Sedangkan sub aspek mengumpulkan fakta yang relevan masih dalam kategori baik tetapi nilainya lebih rendah dibanding sub aspek menggunakan indera. Peserta didik masih mengalami kesulitan dalam mencari informasi dan mengumpulkan informasi yang terkait dengan kegiatan praktikum. Peserta didik, cukup kesulitan dalam hal mencari variabel yang akan diukur untuk menghitung nilai ketidakpastian dari pengukuran benda meliputi panjang, luas, volumen, \& massa jenis benda. Berdasarkan hal tersebut, maka peserta didik perlu memaksimalkan seluruh indera yang digunakan dalam mencari informasi-informasi yang berkaitan dengan apa yang akan diteliti/diukur.

2. Aspek Mengelompokkan (Klasifikasi)

Pada aspek mengelompokkan (klasifikasi) memiliki nilai persentase $80 \%$ dalam kategori baik. Aspek ini memiliki tiga buah sub aspek yaitu sub aspek mencatat setiap pengamatan, sub aspek mencari perbedaan dan persamaan, dan sub aspek membandingkan. Sub aspek mencatat setiap pengamatan dapat dilakukan dengan baik oleh peserta didik. Peserta didik mencatat seluruh variabel yang akan diukur dan hasil pengukuran. Sub aspek ini memiliki nilai yang lebih tinggi dibanding dengan sub aspek lainnya. Peserta didik dapat mengelompokkan variabel pengukuran panjang untuk analisis ketidakpastiannya dan pengukuran panjang. Sedangkan sub aspek mencari perbedaan dan persamaan memiliki nilai lebih rendah dibanding sub aspek lainnya. Untuk sub aspek membandingkan, peserta didik cukup 
yakin dalam membandingkan variabel hasil pengamatan tentang variabel yang yang satu dengan variabel pengukuran akan diukur meliputi panjang, luas, yang lainnya dimana hal dilakukan agar volume, dan massa jenis benda yang memudahkan dalam pelaksanaan kegiatan diukur serta cara penggunaan alat ukur pengukuran. Peserta didik, cukup kesulitan panjang. Berdasarkan hal tersebut, pada dalam hal mencari variabel yang akan aspek ini ditekankan pada perolehan data diukur untuk menghitung nilai awal untuk kegiatan praktikum agar ketidakpastiannya hal ini juga berkaitan peserta didik dapat membandingkan datadengan aspek yang pertama.

3. Aspek Meramalkan (Interpretasi)

$$
\text { Pada aspek meramalkan }
$$
data tersebut sebagai bahan prediksi.

4. Aspek Meramalkan (Prediksi)

(interpretasi) memiliki nilai persentase memiliki nilai persentase $67 \%$ dalam $68 \%$ dalam kategori baik. Aspek ini kategori baik. Aspek ini memiliki dua memiliki tiga buah sub aspek yaitu sub buah sub aspek yaitu sub aspek aspek menghubungkan hasil pengamatan, menggunakan pola hasil pengamatan dan sub aspek menemukan pola setiap sub aspek mengemukakan yang mungkin pengamatan, dan sub aspek terjadi pada keadaan yang belum diamati. menyimpulkan. Sub aspek Sub aspek menggunakan pola hasil menghubungkan hasil pengamatan dapat pengamatan dapat dilakukan dengan baik dilakukan dengan baik oleh peserta didik. oleh peserta didik. Sub aspek ini memiliki Sub aspek ini memiliki nilai yang lebih nilai yang lebih tinggi dibanding dengan rendah dibanding dengan sub aspek sub aspek lainnya. Peserta didik dapat lainnya. Peserta didik dapat menentukan pola dalam melakukan menghubungkan pengukuran panjang kegiatan praktikum berdasarkan hasil untuk analisis ketidakpastiannya dan pengamatan variabel pengukuran panjang pengukuran panjang. Sedangkan sub aspek untuk analisis ketidakpastiannya dan menemukan pola setiap pengamatan pengukuran panjang. Sedangkan sub aspek memiliki nilai lebih tinggi dibanding sub mengemukaan yang mungkin terjadi pada aspek lainnya. Peserta didik dapat keadaan yang belum diamati memiliki menentukan pola untuk pengukuran nilai lebih rendah dibanding sub aspek dengan menggunakan alat ukur panjang. lainnya. Pada sub aspek ini, peserta didik Untuk sub aspek menyimpulkan, peserta masih mengalami kesulitan dalam didik dapat menyimpulkan berdasarkan 
mengemukakan kemungkinan yang terjadi dari satu kejadian dan sub aspek untuk keadaan selanjutnya.

\section{Aspek Mengajukan Pertanyaan}

Pada aspek mengajukan pertanyaan memiliki nilai persentase $72 \%$ dalam kategori baik. Aspek ini memiliki tiga buah sub aspek yaitu sub aspek menggunakan kaidah what why how, sub aspek meminta penjelasan, dan sub aspek bertanya berdasarkan hipotesis. Sub aspek menggunakan kaidah what why how dapat dilakukan dengan baik oleh peserta didik. Peserta didik dapat menggunakan kaidah what why how dalam mencari variabel pengukuran panjang untuk analisis ketidakpastiannya dan pengukuran panjang. Sedangkan pada sub aspek meminta penjelasan, peserta didik baik dalam mencoba meminta penjelasaan terkait apa yang dipraktikumkan. Pada sub aspek bertanya berdasarkan hipotesis, peserta didik cukup kesulitan dalam menyusun hipotesis praktikum pada pengukuran panjang. Berdasarkan hal pad tersebut, maka diharapkan peserta didik perlu memahami konsep dasar materi yang dipraktikumkan.

\section{Aspek Berhipotesis}

Pada aspek berhipotesis memiliki nilai persentase $70 \%$ dalam kategori baik. Aspek ini memiliki dua buah sub aspek yaitu sub aspek mengetahui bahwa ada lebih dari satu kemungkinan penjelasan menyadari bahwa suatu penjelasan perlu diuji kebenarannya dengan melakukan cara pemecahan masalah. Pada kedua sub aspek ini peserta didik mengalami kesulitan dalam menyusun hipotesis hal ini dikarenakan peserta didik berkaitan dengan aspek meramalkan (prediksi) yang memiliki nilai rendah.

\section{Aspek Merencanakan Percobaan}

$$
\text { Pada aspek merencanakan }
$$

percobaan memiliki nilai persentase $78 \%$ dalam kategori baik. Aspek ini memiliki empat buah sub aspek yaitu sub aspek menentukan alat/bahan/sumber yang akan digunakan, sub aspek menentukan variabel/faktor tertentu, sub aspek menentukan apa yang akan diukur, diamati, dan dicatat, dan sub aspek menentukan apa yang akan dilaksanakan, berupa langkah kerja. Pada aspek ini, secara keseluruhan peserta didik mampu dalam merencanakan percobaan. Namun, pada sub aspek menentukan variabel/faktor penentu masih cukup kesulitan dimana hal ini berkaitan dengan aspek meramalkan (interpretasi).

\section{Aspek Menggunakan Alat/Bahan}

$$
\text { Pada aspek mengelompokkan }
$$
(klasifikasi) memiliki nilai persentase $75 \%$ dalam kategori baik. Aspek ini memiliki tiga buah sub aspek yaitu sub aspek memakai alat/bahan, sub aspek 
mengetahui alasan mengapa menggunakan pengukuran panjang. Hal ini menunjukkan alat/bahan, dan sub aspek mengetahui bahwa peserta didik dapat menganalisis bagaimana menggunakan alat/bahan. hasil pengukuran berdasarkan konsep Secara keseluruhan, peserta didik mampu dasarnya.

dalam melaksanakan kegiatan praktikum 10. Aspek Berkomunikasi

khususnya penggunaan alat dan bahan Pada aspek berkomunikasi praktikum. Peserta didik dapat memiliki nilai persentase $75 \%$ dalam menggunakan alat praktikum meliputi kategori baik. Aspek ini memiliki enam mistar, jangka sorong, \& mikrometer buah sub aspek yaitu sub aspek mengubah sekrup untuk pengukuran panjang. Selain bentuk penyajian, sub aspek itu, peserta didik dapat menggunakan menggambarkan data empiris hasil dengan benar alat ukur tersebut walaupun percobaan berupa grafik/bagan/tabel/ ada beberapa peserta didik yang masih diagram, sub aspek menyusun dan kesulitan dalam membaca skala pada alat menyampaikan laporan, sub aspek ukur tersebut. Berdasarkan hal tersebut, menjelaskan hasil laporan, sub aspek aspek ini perlu ditekankan pada membaca grafik/tabel/bagan/diagram, dan keterampilan peserta didik dalam sub aspek mendiskusikan hasil kegiatan. menggunakan alat dan bahan praktikum. Secara menyeluruh, peserta didik memiliki 9. Aspek Menerapkan Konsep

Pada aspek menerapkan konsep dimana peserta didik mampu dalam memiliki nilai persentase $74 \%$ dalam menyampaikan hasil kegiatan praktikum kategori baik. Aspek ini memiliki dua dengan baik dan jelas berdasarkan analisis buah sub aspek yaitu sub aspek data yang digunakan.

menerapkan konsep yang telah dipelajari Berdasarkan hasil analisis dan sub aspek menggunakan konsep pada keterampilan proses sains peserta didik pengalaman baru untuk menjelaskan apa diatas, menunjukkan bahwa secara yang sedang terjadi. Pada aspek ini, menyeluruh peserta didik memiliki peserta didik cukup mampu dalam keterampilan proses sains yang baik menerapkan konsep analisis melalui bahan ajar multimedia interaktif ketidakpastian pengukuran dan melakukan Alat Ukur dan Pengukuran (Tabel 1). pengukuran panjang. Peserta didik dapat Untuk mendukung peningkatan menggunakan konsep analisis keterampilan proses sains peserta didik, ketidakpastian untuk menghitung hasil maka pembelajaran lebih ditekankan pada 
kegiatan proses sains. Proses sains menunjukkan secara umum peserta didik merupakan salah satu bentuk hakekat berada pada posisi rata-rata baik; dan 2) pembelajaran sains yang dapat Bahan ajar multimedia interaktif alat ukur memberikan peserta didik suatu dan pengukuran dapat meningkatkan keterampilan yang dibutuhkan dalam keterampilan proses sains peserta didik membangun pengetahuan secara mandiri secara signifikansi dimana $\mathrm{p}$-value $=0.051$ (Lete, dkk. 2016).

$>$ sig. 0.05 pada tahap 1 dan tahap 2 .

Keterampilan proses sains penting Berdasarkan hasil penelitian maka untuk dikembangkan dalam pembelajaran dikemukaan saran yaitu perlu ditekankan Sains. Trianto (2010) menyebutkan bahwa dalam pencarian variabel pengukuran, keterampilan proses sains memiliki peranan meliputi: a) membantu peserta didik belajar dalam mengembangkan pikirannya; b) memberikan kesempatan peserta didik untuk melakukan penemuan; c) meningkatkan daya ingat peserta didik;

d) memberikan kepuasan instrinsik kepada peserta didik; dan e) membantu peserta didik untuk mempelajari konsep Sains. Hal ini akan berdampak pada peningkatan motivasi dan hasil belajar peserta didik (Fatimah, -). Selain itu, dipertegas oleh Trianto (2010) bahwa keterampilan proses sains peserta didik akan terbentuk secara maksimal apabila peserta didik melalui proses pembelajaran secara berulangulang.

\section{SIMPULAN}

Berdasarkan hasil penelitian dan hasil analisis data, maka disimpulkan mengenai beberapa hal, yaitu: 1) Hasil mencari informasi-informasi awal (obserbasi), dan menyusun suatu hipotesis dalam kegiatan praktikum. Pengembangan lebih lanjutan dikhususkan untuk mengetahui gambaran keterampilan proses sains peserta didik dengan menggunakan bahan ajar multimedia interaktif Alat Ukur dan Pengukuran berbasis pendekatan behavioristik.

\section{DAFTAR RUJUKAN}

Arikunto, S. 2006. Prosedur Penelitian suatu Pendekatan Praktek. Jakarta: PT Rineka Cipta.

Baharuddin \& Wahyuni, E. N. 2010. Teori Belajar dan Pembelajaran. Yogyakarta: Ar-Ruzz Media.

Budiningsih, A. 2005. Belajar dan Pembelajaran. Jakarta: PT Rineka Cipta.

Demirci, N. 2007. A Study About Students' Misconceptions in Force and Motion Concepts by Incorporating a Web-Assisted Physics Program. The Turkish Online Journal of Education Technology (TOJET). Vol.4. 
Devi, P.K. 2010. Keterampilan Proses dalam Pembelajaran IPA. Jakarta: PPPPTK IPA.

Dimyati \& Mujiono. 2006. Belajar dan Pembelajaran. Jakarta: Rineka Cipta.

Fatimah, S. - . Analisis Keterampilan Proses Sains Siswa Kelas V Pada Mata Pelajaran IPA. Prosiding Seminar Nasional KSDP Prodi S1 PGSD.

Hayati, S., Budi, A. S., \& Handoko, E. 2015. Pengembangan Media Pembelajaran Flip Book Fisika untuk Meningkatkan Hasil Belajar Peserta Didik. Prosiding Smeinar Nasional Fisika (E-Journal). Volume IV, Oktober 2015.

Husni, A., Juanda, E.A., \& Hamidah, I. 2010. Model Pembelajaran Kooperatif Berbantuan Web pada Materi Fluida Statis untuk Meningkatkan Pemahaman Konsep Siswa SMA. Prosiding Seminar Nasional Fisika 2010. p 451-458.

Lavonen, J. 2005. Learning and the use of ICT in Science Education. Effective use of ICT in Science Education (EU-ISE).

Lete, M., Sutopo, \& Yuliati, L. 2016. Peningkatan Keterampilan Proses Sains Siswa Melalui Pembelajaran Discovery Topik Tekanan Hidrostatis. Prosiding Seminar Nasional Pendidikan IPA Pascasarjana UM. Volume 01 2016.

Nazeri. 2013. Penggunaan e-Flipbook dalam Topik Elektrik dan Elektronik: Inovasi dalam Pengajaran Reka Bentuk dan Teknologi PISMP RBT. Prosiding Seminar Penyelidikan IPG Zon Timur. Volume 01 No 012013.

Nuraeni, E., Taufik, R., \& Mia, H. A.
2007. The Effectivenness of Audio Visual Teaching Media In Supporting Student Learning of Human Growth. (http//file.upi.edu/Direktori/FMIP
A/JUR._PEND._BIOLOGI/19760

6052001122-

ENI_NURAENI/MAKALAH/mak alah_lengkap_AV_LS.pdf), diakses 20 Januari 2014.

Putra, I.A, \& Sujarwanto, E. 2016. Bahan Ajar Alat Ukur dan Pengukuran Fisika Berbasis Inkuiri Terbimbing. Jurnal Pendidikan Sains Pascasarjana UM, Volume 04 Nomor 03 September 2016.

Rahayu, E.S., \& Nuryata, I.M. 2010. Pembelajaran Masa Kini. Jakarta: Sekarmita Training Publishing.

Ramdania, Diena Randa. 2013. Penggunaan Media Flash Flipbook dalam Pembelajaran Teknologi Informasi dan Komunikasi untuk Meningkatkan Hasil Belajar Siswa. Artikel Ilmiah Tugas Akhir. Bandung, UPI.

Resta, P., \& Laferriere, T. 2007. Technology in Support of Collaborative Learning. Education Psychology Rev. 19: 65-83.

Rustaman, N. 2005. Strategi Belajar Mengajar Biologi. Cetakan I Malang: Universitas Negeri Malang.

Sanyata, S. 2012. Teori dan Aplikasi Pendekatan Behavioristik dalam Konseling. Jurnal Paradigma, Vol. 14.

Semiawan, C. et.al. 1992. Pendekatan Keterampilan Proses, Bagaimana Mengaktifkan Siswa dalam Belajar. Jakarta: Gramedia.

Sudjana, N. 2005. Metode Statistika. Bandung: Tarsito.

Sugianto, D., Abdulloh, A. G., Elvyanti, S., \& Muladi, Y. 2013. Modul Virtual: Multimedia Flipbook Dasar Teknik Digital. INVOTEC. Volume IX No. 02 Agustus 2013.

Sulastiani, Nurhayati, \& Aslim. 2012. Analisis Keterampilan Proses Melalui Metode Eksperimen Dalam Pembelajaran Fisika Pada Siswa Kelas VIII SMP Negeri 1 Makasar. Jurnal Sains dan 
Pendidikan Fisika. Volume 08 Nomor 032012.

Tasri, L. 2011. Pengembangan Bahan Ajar Berbasis Web. Jurnal MEDTEK. Volume 3 Nomor 2.

Teknoanimasi. 2010. Flip Book dan Thaumatrope, (http//teknoanimasi.blogspot.com/ 2008/11/flip-book-danthaumatrope.html), diakses 25 Januari 2016.

Trianto. 2010. Model Pembelajaran Terpadu. Jakarta: Bumi Aksara.

Wijayanto, A. A. 2011. Ncesoft Flip Book Maker Membaca E-Book Lebih Nyata Refernsi Spesifikasi, Berita terbaru_New Triks Tips Komputer, (http $/ / w w w . t o m b o l e s c . c o m)$, diakses 23 Januari 2016. 